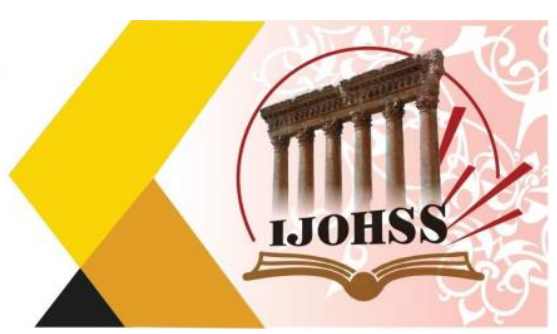

\title{
Contemporary Arab Conceptual Art and Idea Connection to Reality (Analytical Study)
}

\author{
Mohammad Ahmad Bani Salameh \\ Luminus Technical University College \\ 11118 Amman, Jordan \\ msalammeh@yahoo.com
}

\begin{abstract}
This study is discussing the implication of the idea on contemporary Arab conceptual art, and how connected is to reality, It turned out that contemporary Arab reality had an impact on the idea presented in Arab conceptual art, the study have analyzed four artworks (sample study) in terms of the idea, the four analyzed samples are contemporary Arab conceptual art during 2000-2020, to emphasize whether contemporary Arab reality is influencing the idea presented in conceptual artistic works or not, as a result the study have testified that there was an impact of contemporary Arab reality on the idea presented in Arab conceptual art, despite the limitations of contemporary Arab conceptual work.
\end{abstract}

Keywords: Contemporary Art, Conceptual Art, Idea, Contemporary Arab. 


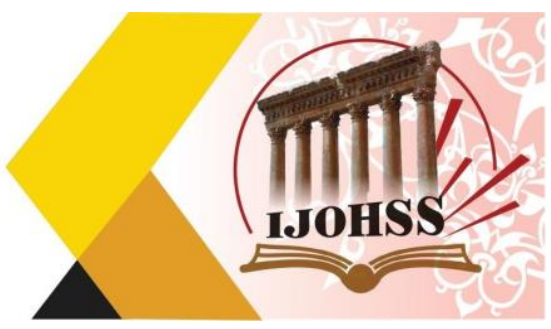

\section{Introduction}

In this time of the early third decade of the twenty-first century, it has become remarkable for the followers of plastic art. The expansion of art events that attract highly motivated artists, whom able to visualize the artwork outside the traditional frameworks, based on concepts within which fundamental questions are raised (Aldulemi, 2021).

This art was initiated on ideas and concepts that establish and adopt the artwork rather than offering artwork with technical skills or esthetic pleasing. These concepts and ideas were derived from several sources such as philosophy, feminism that calls for gender equality, theories of psychological analysis, political practices, body...etc. (El Masry, 2016)

Such type of art is characterized as more humane and has an educational and social function, as it gives the viewer the information to search for concepts and ideas, and differs from the nature of the morphological visual artist who only offers something visually beautiful or ugliness (Allasqah \& Al-Rasheed, 2018).

The conceptual art structures are the best in reflecting the postmodern philosophy, and an express ion of artist ideas, taking no consideration of the quality of the final result as this required for other works subjected to traditional framework requirements, so the artist is putting himself in a statue of full isolation of the common taste, standing in an open space breaking into a free area holding his ideas to create an innovative structure (Aldulemi, 2021)

the concept is the most important aspect of the artwork, according to Sollewitt "the idea becomes an art machine" and adds "ideas can be artworks " and also stressed that "direct concepts often inspire the most powerful work" (Gotthardt, 2020).

according to Tolstoy art book named "what is art " he believed that art significance is of being connected to life and modern issues, as it will lose this value if it moves away from the main goal, on the other hand philosopher Marcuse noted that art was essential in modern societies and the significant role that art played community's modern issues (Spens, 2013) whereas the political situations were considers as one of the most significant issues and situations effected and are affected by the contemporary art in the world in general and in the Arab region particularly due to many challenging political events (Haidar, 2012) stressed that the Arab region has faced more difficult situations than any regions in the world. At the beginning of the twenty-first century, the Arab region had witnessed a horrific political events that had aggravated and caused the birth of the Arab spring

Based on what Haidar has said and what we see today of internal conflicts, revolutions and repression of the ruling class, we realized that the Arab nation is one of most world's conflicting regions in the world, due to internal and external political 

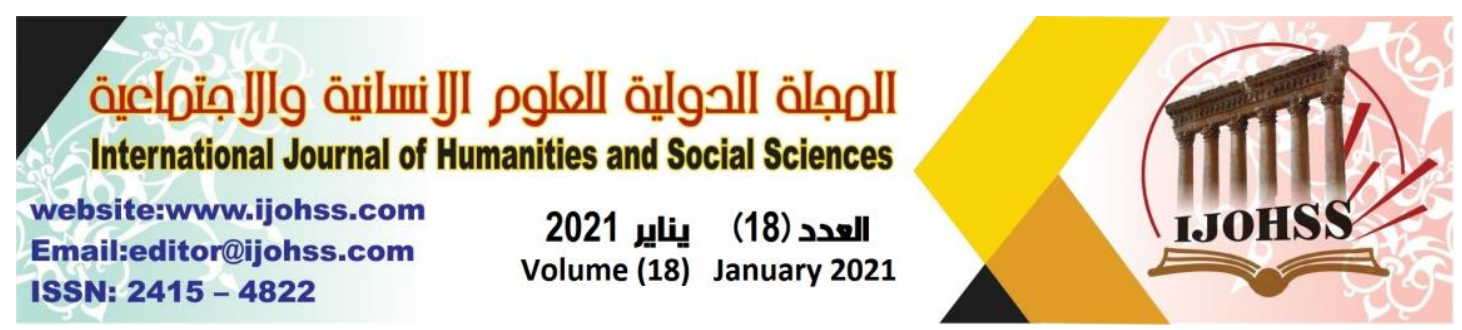

conflict, where these events certainly affecting negatively or positively on varied spheres of life.

According to Mar'ae (1985) he noted that internal and external risks and challenges have a clear impact on the Arab society, and pointed out that art is a significant field in life affects and is affected by the surrounding conditions

ALyasiri (2019) agreed with Mari that there is a common relation between the individual, society and the surrounding environment, pointed out on the impact of the surrounding environment on stability, peace, development, culture, freedom, and others, all of these impacts are assisting in the development of, science, technology, literature, and social industrial aspects,

The political situation is now more influential, the director of the international contemporary art gallery (Minas Art) Laure Diotevil emphasized that the political challenges faced by the Middle East region "the Arab Spring" contributed on a rapid growth of contemporary art in some Arab countries (Bashir, 2011)

We have observed in the contemporary Arab conceptual art that it has been influenced by the political conditions around, and this was reflected in the many artworks have been disused in this research. This research is examined the impact of the idea on contemporary Arab conceptual art to discover its relevance to current reality

\section{Problem of the research}

Smith (2012), Setlar (2010), Melkonian (1997), Ramadan (2014), Hard (2014), Seismpolire (2015), Demirel (2012), Al-Qumari (2009) and Obaidat (2013).

(Abed Alabbs, 2012), (Ilwan, 2018) Most of these studies and have focused on the relationship between contemporary art and politics in general. some studies have focused on techniques being used in conceptual art (Abed Alabbs, 2012), communication mechanisms in conceptual art (Ilwan, 2018), and the conceptual shifts in plastic art. (Rashid, 2018) on the conceptual art of epistemological methods (Ahmed, 2017), Smith (2012) and Melkonian (1997) discussed in general the impact of political attitudes on contemporary art in the Arab world and the Middle East. Smith (2014) the presentation of the problems faced by Egyptian society and the presentation of the technical practices that took place in public space during the revolution in Egypt, and furthermore the impact of art in these places under the political changes, Melkonian argued political attitudes have affected many of middle eastern artist's artworks particularly of those who have lived part of their life as a refugees and how they have been able to express their concerns, ideas and feeling through contemporary artworks. (Ramadan, 2014) stressed in his article that is required to develop new technical system in order to meet changes taking place in the region and in the history of art needs, as the researcher believe that this is the right 


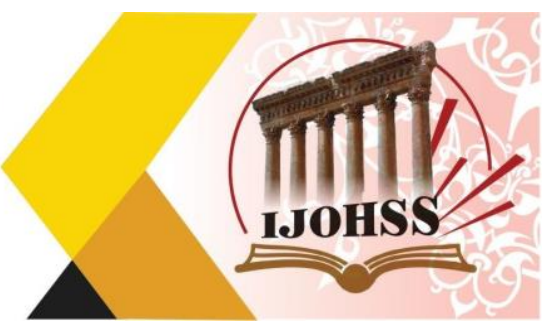

time for such change of the art strategy in the Arab region as the main goal of art is contribute in guiding the future.

However, there were no previous studies or research that confirmed the impact of the idea on contemporary Arab conceptual art and its relevance to reality, although conceptual art focuses on the idea as a key advantage of becoming an art-making machine.

therefore, this study is significant in reviewing the impact of the idea on contemporary Arab conceptual art and its close connection with the living reality.

\section{Methodology:}

This study addresses the impact of the idea on contemporary conceptual art in the Arab world, whereas the researcher will use a descriptive analytical approach to achieve his goal.

The researcher will collect, describe, and analyze the information available through books and publications, studies, researches, and articles on artworks (sample study), to reach the main thought of these artworks, and determine the impact of the idea on contemporary Arab conceptual art and its relevance to reality. Finally get the conclusions that prove the assumptions of this research.

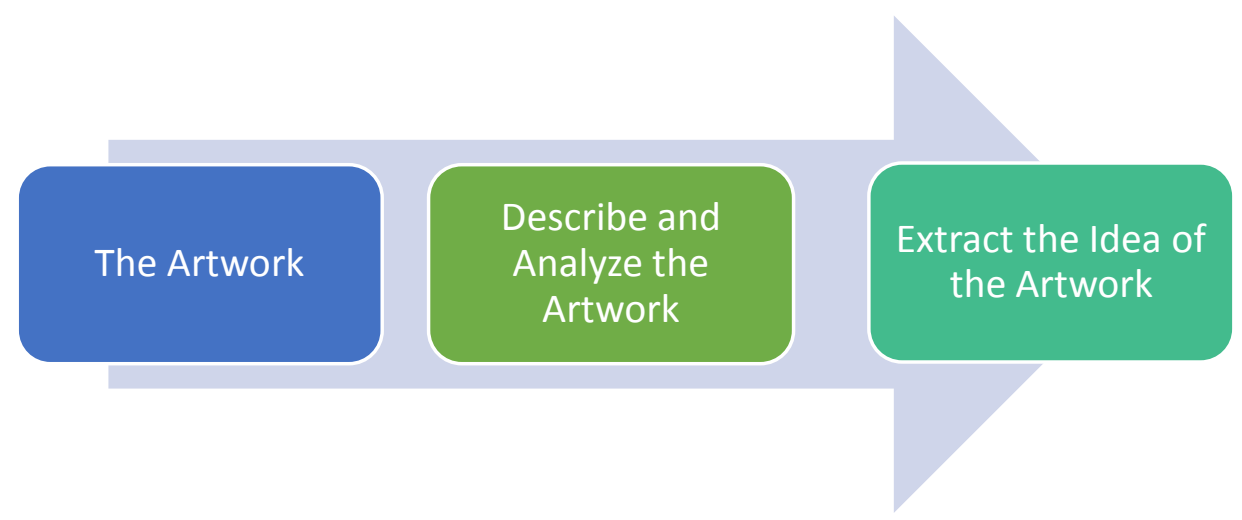

Figure 1: Descriptive Analytical Framework 


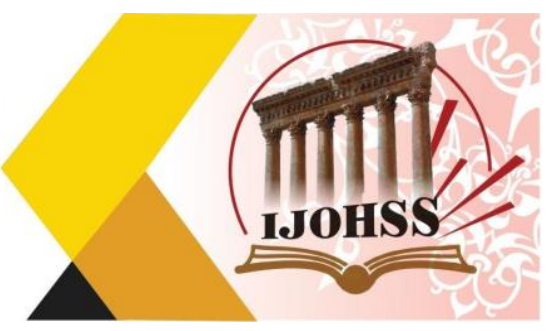

Artwork (1):

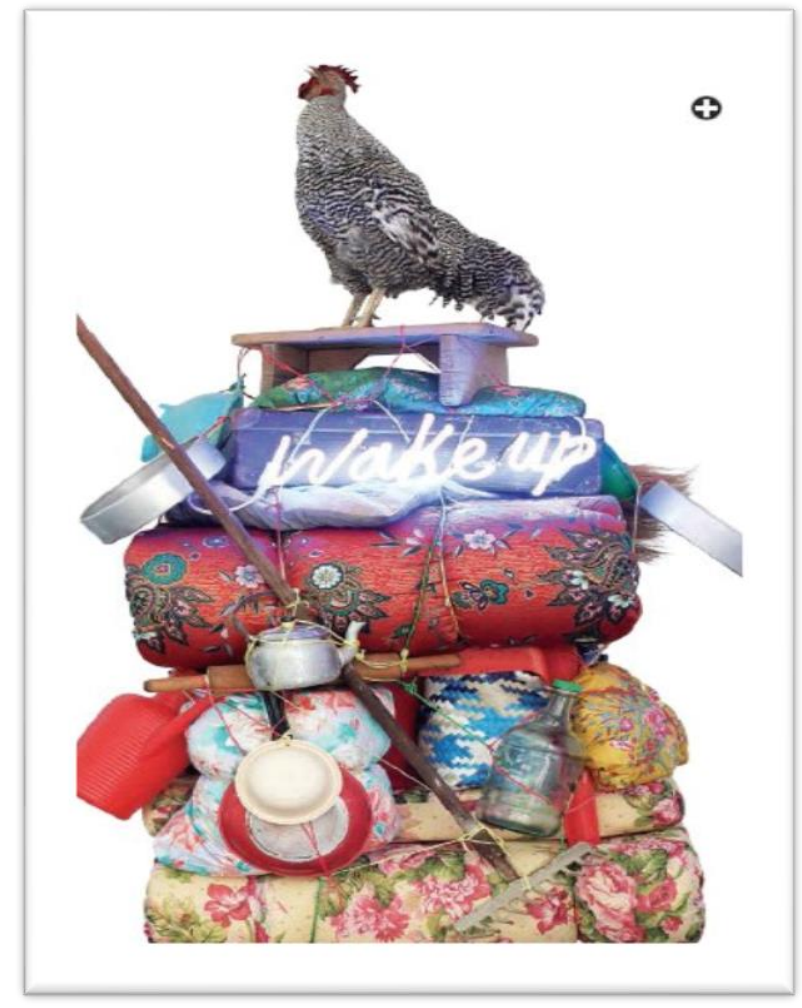

Figure 1: Wake up by Ayman Balbaki (Lebanon) (2012)

\section{The idea of the artwork:}

There are two aspects of Ayman Balbaki's Artwork: The rural world represented by the aspects of domestic life (sheep, parents, mattresses) or the printed fabrics imported from Africa used by women in southern Lebanon, and the urbane world that seems metaphoric, through its buildings. these two worlds are linked through immigration and displacement issues (Tammros, 2019).

it is worth mentioning that Ayman Baalbaki has not only made art through his brush and color, but also his pioneering experience in processing, which is not included in his documentations of war. with the bias toward common human concerns and suffering from displacement, and the wounds that war has made (Othman, 2016). 

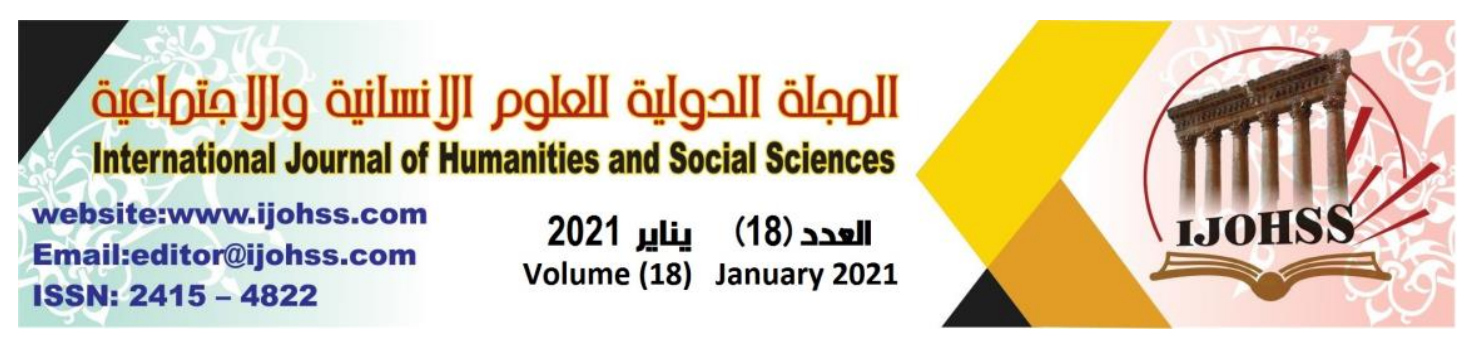

\section{Discussion:}

If we look at the artist's work (Ayman Baalbaki), we will realize that he has unleashed his feelings regarding political issues and problems facing the Arab World This was embodied in a form of contemporary art, called conceptual art.

It is clear that this artwork has a strong relation with reality, as it raises the issue of wars and the consequences of immigration and displacement of citizens, which are the Arab citizen suffers from in general.

\section{Artwork (2):}

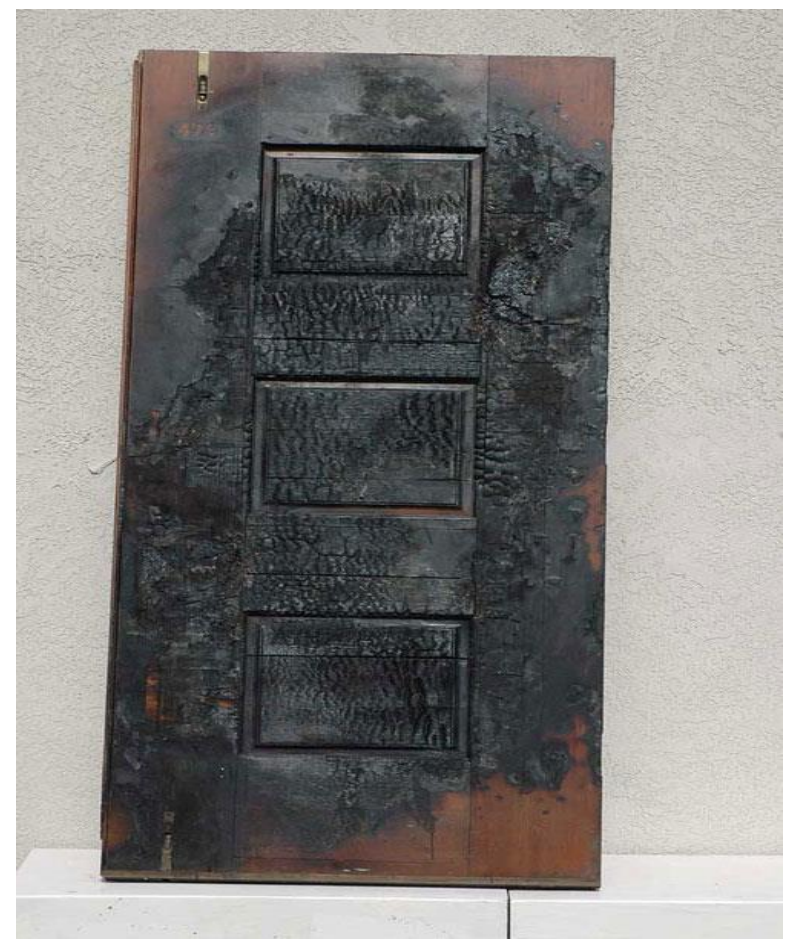

Figure 2: Burned doors of Baghdad by Mohammad Al-Saaduon (Iraq) (2009)

\section{The idea of the artwork:}

Al-Saadoun was dedicated to express the Middle East issues, especially Iraq, and adopted in his work on symbolism that creates his self-belonging to the geography of the place as he does not present it similarly, yet with visual symbols connected with the idea in the conceptual style, in order to hold a rational, readable, profound sensory reaction of the metaphysical visual cue significance that reflects reality and presents a deep message of the artwork (Bin Fatima, 2017 a). 


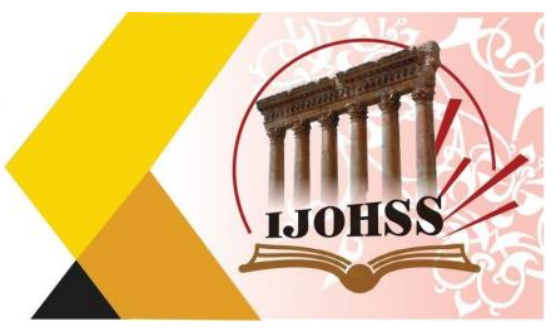

Saaduon have expressed in his artwork "burned doors of Baghdad" about The IraqiIranian conflict and the psychological implication on individuals, cities, and scratching the history of Iraq by burning those doors, as he was a witness of such event and it never left his memory so the pain of burning the doors of Baghdad were it was a gate for peace, life and calm in his mind and a connection between The city's cleavage with history and civilization has been transformed into a separation of security and safety from individuals and displacement within the homeland ,that was carefully articulated by Saadoun through a combination of colors, letters, cloth, wood and the door itself, maintaining the accuracy of the accomplished work and the sense of the motive in its meaning (Bin Fatima, 2017 a).

His idea was affected with the reality of his homeland, his feelings, attitudes were addressing changing events,

where he was affected by the tragic Scenes of stained chairs and books, burned doors Stuck in his memory passing to his imaginations that was interacted with his attitudes artistically to create visual aesthetic expressive restorations.

despite of its ugliness Saadoun have formulated his idea and reflected Iraq in details from history to civilization using row materials, calligraphy and decorations (Bin Fatima, 2017 b).

\section{Discussion:}

the artist (Mohammad Al-Saadoun) expressed what is happening in the Middle East, especially Iraq his country, and the significant impact of these wars on the population, he meant the implications of the Iraqi-Iranian conflict on people, cities and civilization in general, as wars distort reality, burn it and destroy civilization with its components.

This artwork shows the strong relation between it and the living reality particularly in Iraq and the Arab world in general, pointing out the consequences of wars and conflicts in these countries such as insecurity, and distortion of history and civilization. 


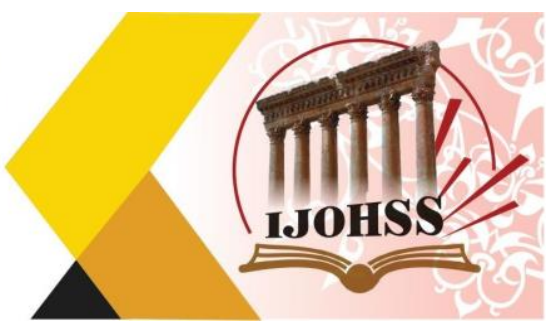

\section{Artwork (3):}
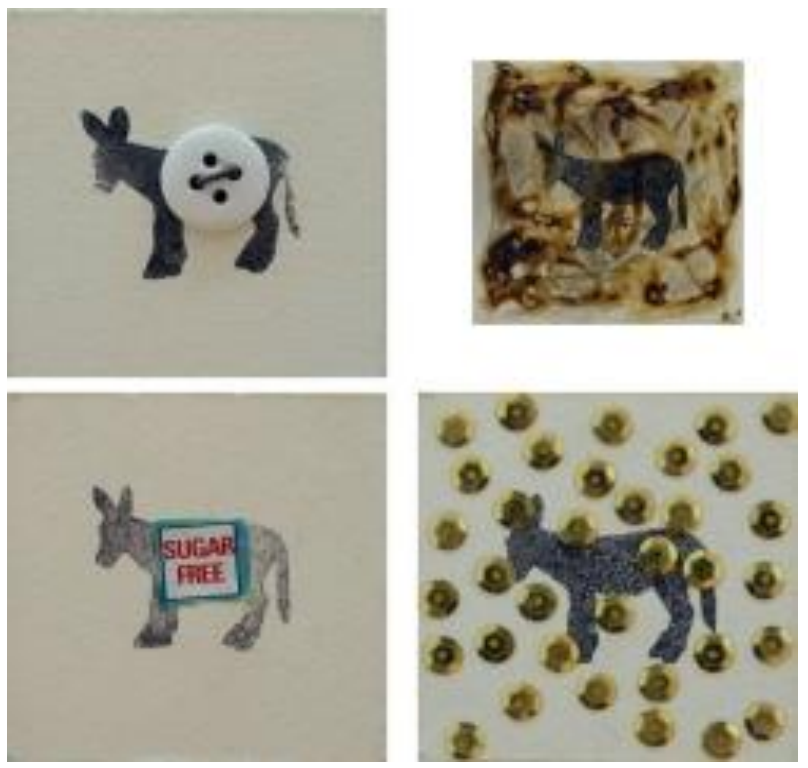

Figure 3: A Donkey made in Palestine by Ashraf Fawakhri

(Palestine) (2017)

\section{The idea of the artwork:}

His dedication has motivated him to create his artistic work according to an idea of rupture and geography Psychologically and psychologically, and presented it as part of his participation in "made in Palestine" (Farahat Alfan gallery for humanity), which was held in the United States, in order to support the Palestinian issue. His artistic works collection has inspired of the gallery name, the collection was consisted of 48 artistic works names" a donkey made in Palestine" as the main character was "donkey" The symbol considered by Fawakhri is the closest sign that can express the suffering of the Palestinian, his burdens and his differences in everything he has lived in geography since the Nakba of 1948 (Bin Fatima, 2017 c).

Fawakhri contemporary style through direct expression, as it turns reality into an ironic one as the conflict today turns it into symbols that are visually listed in a form that contrasts with the meaning of a life and morality in harmony with the concept of the self-influence, which in turn carries out effective reactions his symbols are part of the reality as "donkey" represent a true belonging figure of his land, bearing all his misery, persistently, with patience, full fulfillment, and dedication, he as a human being he have not given up on his complex affinities and identity He is "donkey," as it seen in his artwork "I'm a donkey" sometimes he shows his self-riding his donkey as a symbolism of Christ, who was a passenger in the earth and nature wisely, in balance and love, and sometimes his donkey is riding him in an illogical ironical way he lives 


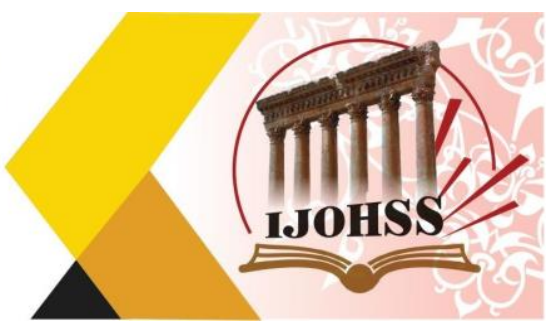

on this cynical contradiction between crying and joy, on the surface, the idea seems to be the culmination of a conflict, but it is the complex reflections of the two-tiling, overlapping, and visual intensity between reconciliation and the rivalry, hustle and bustle ,history and geography, survival and expulsion, acceptance and marginalization (Bin Fatima, 2017 c).

The artist chose the character of the donkey in his art as the accepts reality and recognizes the difficulties of everyday life, and feeds his abundant and restive works, a painting of a painting and an idea of a sequential proportional idea from the donkey character, that cultural figure has been transformed was a disputed one by many cultures, the artist is using donkey as a tool for criticizing occupation methods of siege and destruction (Melhem, 2015).

\section{Discussion:}

By what we see in the work of the artist (Ashraf Fawakhergi), and what has been written about this artistic work, the artist presents the suffering of the Palestinian people and the difficulties and difficulties they face as a result of the occupation, the donkey was used by Fawakhergi as a symbol of this suffering, in doing so, he affirms his belonging to his people and homeland through the use of the character of the donkeys as a means of criticism of the methods of occupation against the siege and destruction of the Palestinian people.

Consequently, the work of the Palestinian people and the suffering of the Palestinian people has been critically raised to this challenging reality

\section{Artwork (4):}

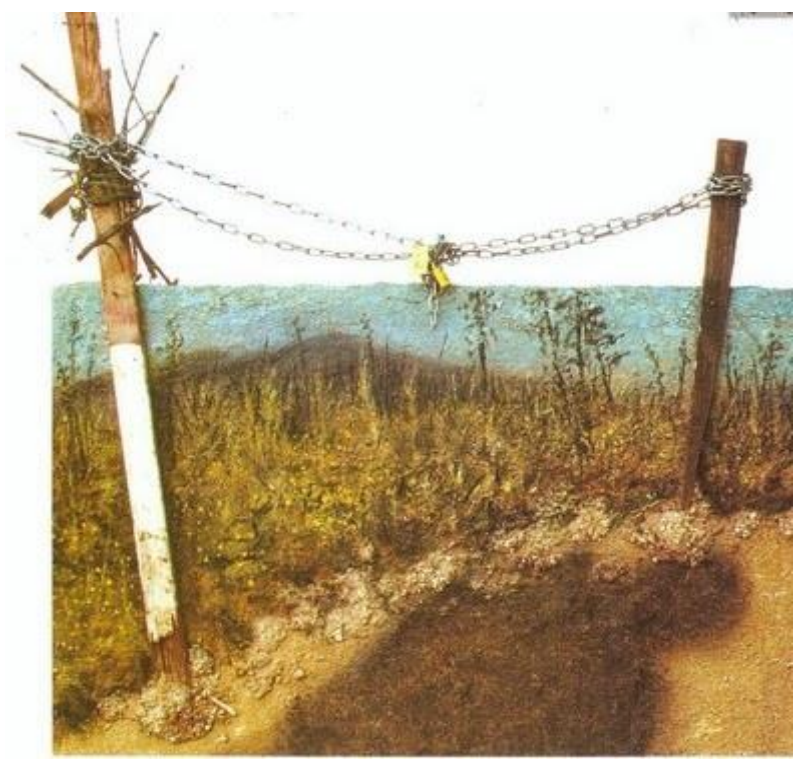

Figure 4: Khiyam detention center by Elham Farajani (Libya)

(2002) 


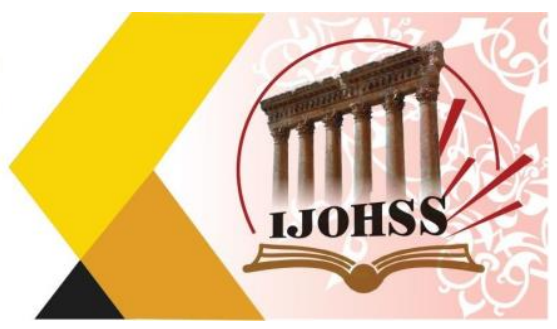

\section{The idea of the artwork:}

She is trying to engage conceptualism in many aspects and various expressions that are not separated it from the familiar panting however she turned her artistic concepts into modernity through dealing with the idea, as she adopted the theatrical performance to express humanity in performance, in Khiyam detention center's painting the natural materials used the stone and the branches were tied together by a series of tricks to the place in its imagery of the idea of families and freedom. (Bin Fatima, 2017 b).

It expresses freedom and liberation, humanity and truth, for the implementation of this painting, she used natural element Al khayyam land, as symbols that expressed constancy and idea also expressed the brutality of torture, and a preciously painting charged with anxiety, as she raised two rough blocks in a string as an expression of prison (Bin Fatima, 2016).

\section{Discussion:}

It is noted in the artistic work of Elham Farjani that there is a clear expression of the of Arab people's suffering, and the Palestinian people suffering, families and blockades in particular, their need for freedom and the removal of restrictions that limit their sense of freedom. It is clear that there is a strong connection between the idea presented by the artistic work of the Palestinian people and the siege and the prevention of freedom that the Palestinian people suffers from in particular.

\section{Results:}

These experiences consider as some of the other deep and diverse Arab experiences that have been adopted conceptually as an innovative path starting from the idea then relying on various means that the artist sees as a good tool for his concepts, it is a tool of expression and a representation of the surrounding reality and current issues.

The researcher is clearly see the strong and resurgent relationship between these conceptual works and reality by raising important issues that affect the Arab world, which suffers from these problems and difficulties, thus seeing the impact of contemporary Arab realities on the ideas presented in contemporary works of art. 


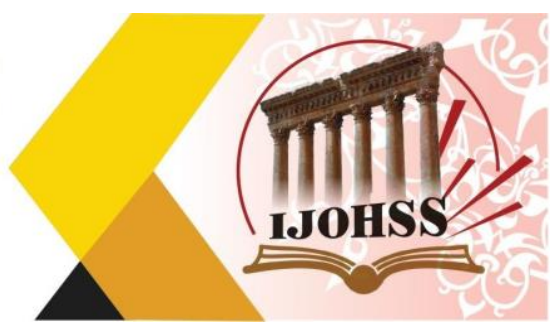

\section{References}

1- Aldulemi, M. Y. (2021, January 2). Contradictory aesthetic awareness in the structures of Western conceptual art. Alquds. Retrieved from https://www.alquds.co.uk.

2- El Masry, W. A. (2016, February 16). The Second Fine Arts and International Community Service Conference. In Academia. Retrieved from https://www.academia.edu.

3- Allasqah, S. I., \& Al-Rasheed, I. B. (2018). Conceptual transformations of contemporary Saudi art. Journal of Fine Arts and Art Education, 1(2), 147-175. Retrieved January 18, 2021, from https://jfea.journals.ekb.eg/article_75932_6d6ac5f862d72afe657d2ced303a7358.p df.

4- Abed Alabbs, A. (2012). Manifestation techniques in conceptual art. Al-Academy, (63), 93-104. Retrieved January 18, 2021, from https://www.iasj.net/iasj/article/50513.

5- Gotthardt, A. (2020, January 27). Sol LeWitt on How to Be an Artist. Retrieved January 18, 2021, from https://www.artsy.net/article/artsy-editorial-sol-lewittartist.

6- Mohammadd, B., \&amp; Jaber, S. (2015). Contemporary art styles and trends (1st ed.). Baghdad: Al Fateh Office. Retrieved January 18, 2021, from https://www.noor-book.com.

7- Haidar, R. (2012). Revolutions of the Arab Spring, and the future of the Arab political system. In Alasmarya University Journal, 24,511-576.

8- Mar'ae, T. (1985). Studies in Arab Society. Amman, Jordan: Union of Arab Universities.

9- Spens, C. (2013). Contemporary art and political violence: the role of art in the rehabilitation and healing of communities affected by political violence. Journal of Terrorism Research, 4 (1), 19-41. Retrieved from http://doi.org/10.15664/jtr.621

10- ALyasiri, S. (2011). Art and its social and educational role and the possibility of activation in Arab societies. Journal of Kufa Studies Center, 1 (79), 65-88.

11- Bashir, M. (2011, July 11). Minas Art... The Arab Spring contributed to the rapid growth of contemporary art in Arab countries. Kuwait News Agency. Retrieved from https://www.kuna.net.kw/ArticlePrintPage.aspx ?id=2179524\&language=ar

12- Ilwan, T. A. (2018). Communication Mechanisms in Conceptual Art. Funon AlBasrah, 15(16), 9-30. Retrieved January 18, 2021, from https://www.iasj.net/iasj/download/03a41b21af7f34f4.

13- Tammros, N. (2019, April 23). The subject of the ruins in the Artworks of Ayman Baalbaki. Retrieved January 18, 2021, from http://awanmedia.net/culture.

14- Othman, N. (2016, September 15). Ayman Baalbaki and war transcripts. Retrieved January 18, 2021, from https://www.almodon.com. 


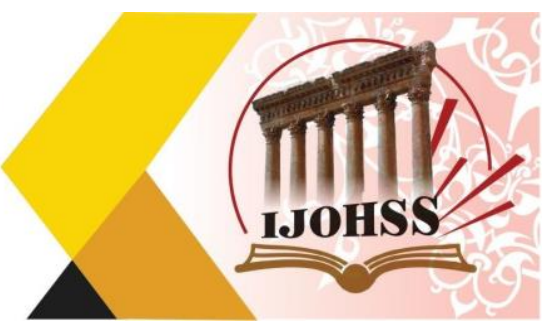

15- Bin Fatima, B. (2017 a, May 8). The experience of the Iraqi artist, Muhammad AlSaadoun. Artsgulf. Retrieved January 18, 2021, from https://artsgulf.com/articles/665975.html.

16- Bin Fatima, B. (2017 b, October 17). Conceptualism and contemporary Arab plastic art, from idea to personification. alwatanvoice .Retrieved January 18, 2021, from https://pulpit.alwatanvoice.com/articles/2017/10/17/447771.html.

17- Bin Fatima, B. (2017 c, August 30). "Made in Palestine" vision by artist Ashraf Fakhry. Artsgulf. Retrieved January 18, 2021, from https://artsgulf.com/articles/669981.html.

18- Melhem, M. (2015, March 1). An art exhibition in Nazareth under the title of persona non grata. Arab48. Retrieved January 18, 2021, from https://www.arab48.com.

19- Ahmed, J. (2017). Plastic art and a discourse behind representations is an epistemological reading of conceptual art. Funon Al-Basrah, 14, 1-6. Retrieved January 18, 2021, from https://www.iasj.net/iasj/download/25e2b44b6c6c3fe8.

20- Bin Fatima, B. (2016, December 5). Experience of Libyan plastic artist Elham Ferjani. Artsgulf. Retrieved January 18, 2021, from http://artsgulf.com/articles/658280.html.

21- Ramadan, K. (2014). New Arab art order. Contemporary Practices. XV, 28-33.

Retrieved from http://www.contemporarypractices.net/essaysv15.html 